\title{
Comparing the effect of price and the effect of brand on industrial lubricants customers' buying choice
}

Mohammad Reza Karimi Alavijeh

Alameh Tabatabayi University, Faculty Member, Business Management Ph.D mr.larimi20@gmail.com

Seyedeh Sara Fattahi

Tabarestan Higher Educational Institute, Mazandaran Iran

s_s_fattahi@yahoo.com

Marjan Moshfegh

Islamic Azad University, Business Management International Marketing M.A. ma1moshfegh@gmail.com

\section{Editor Científico: José Edson Lara}

Organização Comitê Científico

Double Blind Review pelo SEER/OJS

Recebido em 06.05.2019

Aprovado em 03.08.2019 


\begin{abstract}
The present research was conducted to compare the effects of price and brand on the industrial lubricants' customers' buying choice. To this end, 106 industrial lubricants buyer organizations in Tehran, Iran were selected as the population of the research. The sample size was equal to the population due to the accessible and limited number of the organizations. The data were collected using a questionnaire comprising 58 items rated on a 5-point Likert scale. The reliability of the questionnaire was determined and confirmed using Cronbach Alpha and confirmatory factor analysis, respectively. In total, 74 usable questionnaires were received for data analysis. The results indicated the significant effects of brand and price on buying choice. Further, the effect of perceived quality on buying choice was significant, but far less significant compared to that of price or brand. The effects from customer information on buying choice of industrial lubricants customers was not significant.
\end{abstract}

Keywords: Buying choice, brand, price, perceived quality, industrial lubricant.

\title{
Comparando o efeito do preço e o efeito da marca em lubrificantes industriais escolha de compra dos clientes
}

\section{Resumo}

A presente pesquisa foi realizada para comparar os efeitos de preço e marca na escolha de compra dos clientes de lubrificantes industriais. Para este fim 106 organizações de compradores de lubrificantes industriais em Teerã, no Irã, foram selecionadas como a população da pesquisa. $\mathrm{O}$ tamanho da amostra foi igual à população devido ao número acessível e limitado das organizações. Os dados foram coletados por meio de um questionário composto por 58 itens classificados em uma escala Likert de 5 pontos. A confiabilidade do questionário foi determinada e confirmada pelo Alpha de Cronbach e pela análise fatorial confirmatória, respectivamente. No total, 74 questionários utilizáveis foram recebidos para análise de dados. Os resultados indicaram os efeitos significativos da marca e preço na escolha de compra. Além disso, o efeito da qualidade percebida na escolha de compra foi significativo, mas muito menos significativo em comparação com o preço ou a marca. Os efeitos das informações dos clientes sobre a escolha de clientes de lubrificantes industriais não foram significativos.

Palavras-chave: Escolha de compra, marca, preço, qualidade percebida, lubrificante industrial.

\section{Comparando el efecto del precio y el efecto de la marca en la elección de compra de clientes de lubricantes industriales}

\section{Resumen}

La presente investigación se realizó para comparar los efectos del precio y la marca en la elección de compra de los clientes de lubricantes industriales. Con este fin, 106 organizaciones de compradores de lubricantes industriales en Teherán, Irán, fueron seleccionadas como la población de la investigación. El tamaño de la muestra fue igual a la población debido al número accesible y limitado de las organizaciones. Los datos fueron recolectados usando un 
cuestionario que comprende 58 ítems calificados en una escala Likert de 5 puntos. La confiabilidad del cuestionario se determinó y confirmó utilizando Cronbach Alpha y análisis factorial confirmatorio, respectivamente. En total, se recibieron 74 cuestionarios utilizables para el análisis de datos. Los resultados indicaron los efectos significativos de la marca y el precio en la elección de compra. Además, el efecto de la calidad percibida en la elección de compra fue significativo, pero mucho menos significativo en comparación con el precio o la marca. Los efectos de la información del cliente sobre la elección de compra de lubricantes industriales para los clientes no fueron significativos.

Palabras clave: elección de compra, marca, precio, calidad percibida, lubricante industrial.

\section{Introduction}

Understanding industrial buyers' behavior is a crucial issue in marketing contributing to effective industrial marketing strategies. Effective implementation of industrial marketing strategies requires understanding customers' decision making and buying choice (Balalian et al.,2017). However, the bulk of marketing literature focuses on buying choice in consumer markets. Despite conceptual and methodological contributions to understand industrial customers' buying choice, there is little empirical knowledge on customers' buying choice in Iranian industrial lubricants markets (Dehdashti \& Kohiari, 2015). This requires identifying determining factors of industrial customers' choice (Johnston, Lewin, \& Spekman, 2009).

An awareness of effective factors on customers' buying a product, as an important part of marketing process is a critical requisite to respond to customers' needs and play a determining role in organizations successful sales to customers in both industrial and consumer markets. But due to the different product nature and purchasing process, customers' buying choice in industrial markets differs from consumer markets (Baily, 2011). The available literature identifies industrial buying choice differences with consumer markets (e.g. intermediate nature of industrial products, small customer base, high-volume purchases and group decision making, buying through agreements) (Bingham, 2012). Buying choice is the decision making process in choosing one product over others involving three stages (i.e. search, information collection, and evaluation). Throughout the process, various factors influence customer's buying choice (Ojo, Kesinro, \& Akinsunmi, 2015).

Price and brand have constantly been reported as two major factors. Price refers to the value from consuming a product and the pricing level and methods in industrial markets may create a positive or negative attitude in the customer's mind thereby influencing customer's buying decisions and choice a product (Srivastava, 2013). Brand fame is another factor which 
is defined and measured in terms advertisement and brand name differentiation from other brands (Ojo, Kesinro, \& Akinsunmi, 2015). Brand has a major role in creating a favorable mental image in the customers' minds. Further, significant positive effect of brand has been reported on customers' product quality perception and thereby, on customers buying choice (Dehdashti \& Kohiari, 2015). Studying brand and price together provides the best array of variables to predict customers' buying choice in industrial markets (Johnston, Lewin, \& Spekman, 2009).

Industrial lubricants with approximately 53 million tons demand in 2016 make up a major sector in global industrial markets, Asia and Oceania, with 42 per cent together, hold the largest share of this global demand. Industrial lubricants are technology-related products which facilitating production processes with wide use in automotive and heavy vehicles. The market has enjoyed ascending growth rate since the advent of the third millennium due to more fuel consumption savings, industrial growth and machinery depreciation prevention. In Iran, 80 per cent of the country's one-million-ton demand for industrial lubricants are supplied by domestic companies including Behran, Sepahan, Iranol, and Pars along with agents of foreign brands such as Castrol and Shell with a small market share. The major volume of industrial lubricants in Iran are sold in the organizational customers sector and are based on agreements (Keshavarzi Bank Securities Co., 2015).

There is little empirical evidence in the literature regarding the effects of brand and price on industrial customer's choice in a single study. Further, not much is known about the purchase decision of industrial lubricants buyers in Iranian markets. This lack of knowledge has resulted in improper pricing and brand building strategies and practices.

\section{Literature review}

A number of studies carried out outside Iran indicate the positive effect of brand on consumer's buying choice. The price difference between products of similar features and quality, but offered under different brands and the direct relationship between brand and consumer's buying choice is reported in (Zeb, Rashis, \& Javeed, 2011). The researchers report that brand is the major factor behind differentiation and achieving competitive advantage and plays an important role in shaping consumer's trust and buying choice. In another descriptive study which is carried out to study the effect of brand on impulsive buying behavior and choice of industrial lubricants Ojo, Kesinro, \& Akinsunmi (2015) have studies buying choice in a large 
population of 2800 industrial lubricant buyers and reported a positive significant correlation between brand and buying choice of consumers. In the conclusion, the researchers attribute brand-created customer's awareness to customer's buying choice of industrial lubricants.

Abdulaziz \& Mustaffa (2015) have descriptively studied the factors on industrial brand value in Malaysian market. The results showed the significant effect of perceived quality, brand loyalty, organization reputation, corporate social responsibility (CSR), and seller-buyer relationship on industrial brand value with perceived quality and loyalty being most significant. Surprisingly, brand awareness was not reported to have significant effect on industrial brand value. The researchers associate this finding with the small number of industrial brands in Malaysian market and argue since purchase center members know all industrial brands in the market, other factors are considered in decision making. The study is limited to home appliances industry with the small number of industrial brand but reveal whenever a dimension of industrial brands is the same or ignored, other dimensions become more important in decision making.

Dhrup, Mafini, \& Dumas (2014) in a descriptive design studied the effects of packaging, price and brand awareness on brand loyalty in paint industries. The regression analysis of the data from a questionnaire based on the concepts from the literature indicated the significant effect of all the three independent variables on customer loyalty. However, brand and price had a far more significant effect compared to packaging. The researchers (2014) concluded brand awareness effects customer choice as customers choose known brands and that brand facilitates identification of product groups under a known brand. Explaining the higher significance of brand effect, the scholars argue brand association leads to brand evaluation in customer's mind. It also determines the price that the customer pays for the brand. Although this effect is reported to be slightly more significant, the scholars fail to explain under what circumstances (e.g. customer's low purchasing power) this finding applies.

Baily (2011) reports interesting findings of comparing price and brand effects in a comprehensive research on customers' buying behavior in industrial lubricant stores in Cape Town, South Africa. The research is title "Customer Buying Behavior at Selected Petroleum Shops in Cape Town" and studies customer's reasons for buying a specific brand and product. The population was 246 petroleum lubricants shops and a non-random target sampling was used. The data were analyzed using descriptive statistics, variance analysis and chi square test indicating significant and positive correlation between brand and general features, and buying 
choice. The price-buying choice correlation was so significant that Baily (2011) considers brand as the major determinant of brand credibility, but makes a distinction between real price perceived (or psychological) price. The researcher sees the importance of price as dependent to the buyer since some buyers prefer convenience or brand, thus evaluating between higher price and the preferred factor.

A research titled "the effect of industrial brand equity on brand performance form the view point of buying center members (study case: home appliances manufacturing companies)" is carried out by Dehdashti \& Kohiari (2015) to identify factors of industrial sellers' brand equity and the relationship with performance. The researchers extracted factors on industrial brand equity and presented a model consisting of brand awareness, perceived quality, brand association, buyer-seller relationship, selection tendencies, reliability and band loyalty dimensions. Then the researchers analyzed the questionnaire data from a population of home appliances manufacturers in Tehran shopping centers. The results confirmed the positive significant effect of brand loyalty, perceived quality, industrial seller's reputation, and buyerseller relationship on industrial brand equity. Perceived quality, was the most significant factor in industrial markets.

On the effect of brand equity in industrial markets, Seydjavadin, Amini, \& Amini (2014) investigated the correlation between customer loyalty dimensions including satisfaction, value, and resistance to change, emotions, trust level, brand value, and brand. The correlation was determined using the Spearman test and structural equation modelling (SEM) and showed significant effects of brand value and trust on customer loyalty which was studied both in behavior and perception. This shows stronger brands and brand loyalty increase customer choice.

Heidarzadeh, Alvani, \& Ghalandari (2011) have carried out a descriptive survey study to investigate the effect of brand social power on purchasing decision. Using structural equation modelling (SEM) to analyze the data from a questionnaire in a population of students, the results of this study generally confirms the effect of brand social power on purchasing choice, but the effect may vary depending on the customer's mental preparedness. The researchers conclude that the effect of brand social power is attributed to creating higher confidence in the customer's mind with respect to brand or product performance. This confidence causes customer's subconscious choice of the brand with higher social power in the purchase process evaluation stage. 


\section{Problem Statement}

So far, no study has compared the effects of price and brand on industrial lubricants customers' buying choice in Iran. This lack of knowledge leaves both scholars and practitioners in industrial lubricants unaware of customer's buying choice. This gap also makes branding and price setting incompatibility with customer behavior and lower success rates. Therefore, the present study focuses on industrial markets to compare price and brand effects on customer's buying choice.

\section{Objectives of the Study}

This is guided by the following objectives:

-To compare the effects of brand and price on industrial lubricants customers' choice;

-To determine the effect of price on industrial lubricants customers' choice;

- To determine the effect of brand on industrial lubricants customers' choice.

In addition, following the framework, this study also aims:

- To determine the effect of perceived quality on industrial lubricants customers' choice;

- To determine the effect of complementary product information on industrial lubricants customers' choice.

\section{Theoretical framework}

The model proposed by Brucks, Zeithmal, \& Naylor (2007) is adopted as the theoretical framework. The model enjoys high level of empirical and qualitative validation. Figure 1 demonstrates the model. 


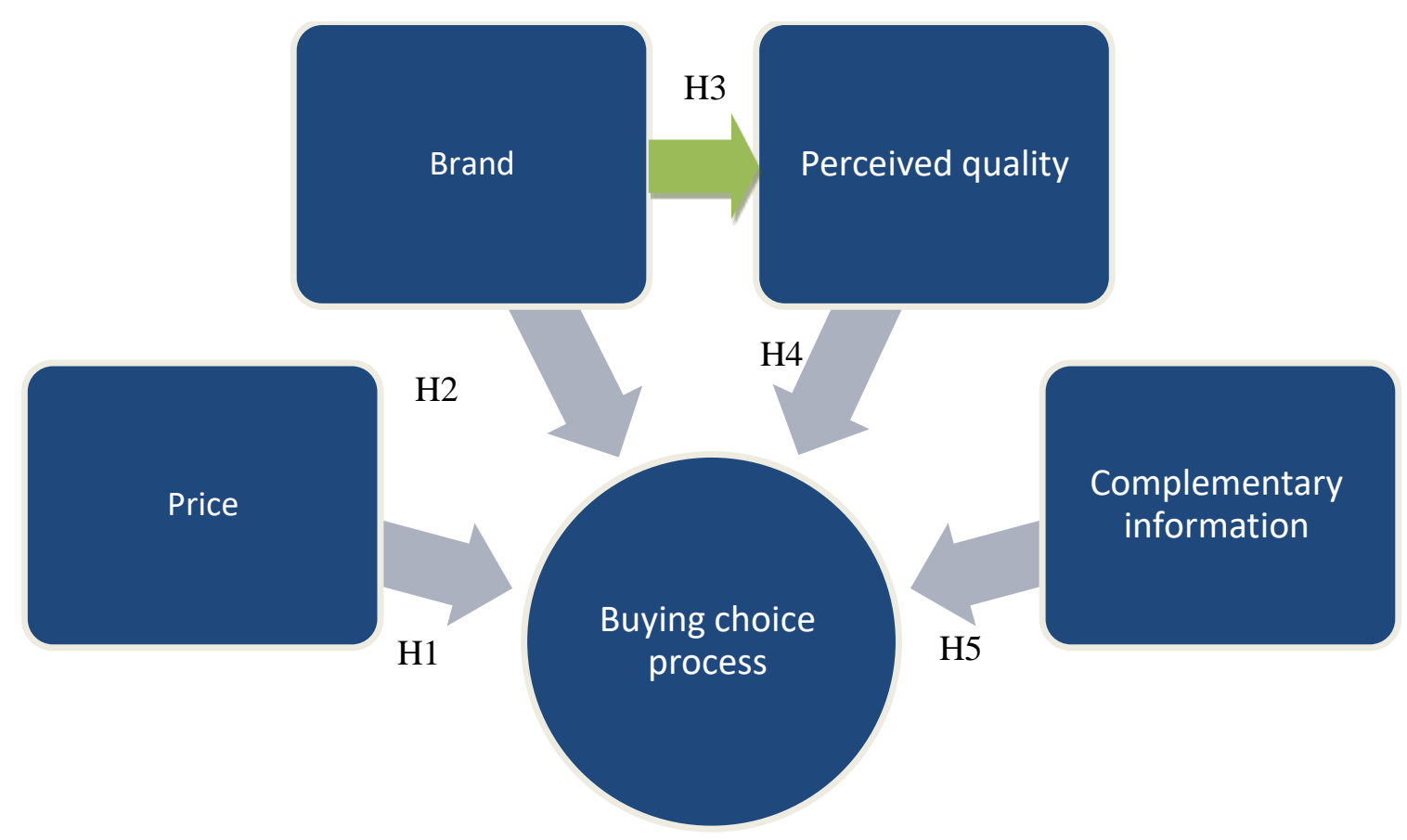

Figure 1: Theoretical Framework (Brucks, Zeithmal, \& Naylor, 2007)

The model consists of four components that influence customer's buying choice. Three variables of price, brand, and complementary information have a direct effect on buying choice while perceived quality, in addition to directly influencing buying choice, is influenced by brand and brand indirectly influences buying choice through perceived quality (Brucks, Zeithmal, \& Naylor, 2007). Each component of the model is explained below. In this model buying choice involves picking a product for buying with three dimensions (i.e. searching price information, brand and perceived quality and other relevant complementary information on brands or products). Price refers to customer's value and is a function of benefits the customer gains by buying and consuming a product, against the costs paid (i.e. lower price, payment conditions, quality). Brand refers to how much a brand name is known with four dimensions (brand name, advertisements coverage, brand reliability/trust, brand differentiation). Complementary information is conditions governing seller-buyer's relationship (e.g. sales volume, competing products, relationship type, purchase volume, information search) (Brucks et al, 2000). 


\section{Research methodology}

This research is carried out based on the present behavior of industrial customers using a questionnaire to collect data and is applied research in terms of purpose. The status quo of the phenomenon under study, (i.e. buying choice) is described a descriptive design is chosen.

\subsection{Timespan}

The research was conducted during the time period from summer to winter, 2016. 6.2.

\section{Research Hypotheses}

To address the objectives of the study, the following positive hypotheses are in the buying process of industrial lubricants, brand has a more significant effect than price.The present research also hypothesizes that:

H1-1. Price has a positive and significant effect on buying choice of industrial lubricants.

H1-2. Brand has a positive and significant effect on buying choice of industrial lubricants.

H1-3. Perceived quality has a positive and significant effect on the quality of industrial lubricants as perceived by customers.

H1-4. Complementary information has a positive and significant effect on buying choice of industrial lubricants.

\subsection{Sampling}

The population consists of 106 sales agents of industrial lubricants and manufacturing factories in Tehran, Iran who use lubricants in manufacturing operations. These entities often consume industrial lubricants as intermediate goods in business activities. Further, to purchase industrial lubricants, the organizations follow an industrial buying pattern where an organizational unit or buying center evaluates the information and makes buying decisions. Therefore, the questionnaires were distributed among those members of these organizations who represent a role player in the decision making and buying choice process. As the population is small enough to provide access to all members, the sample size equaled population. Each questionnaire was sent to one member (representing the organization) and 74 completed questionnaires could be used in data analysis. 


\subsection{Data Sources}

To identify the influencing factors (brand, price, complementary information and perceived quality, systematic literature review was used to identify the dimensions of the variables (Majumder, 2015). Then, based on the identified variables, questionnaire was constructed and was distributed among the participants. The completed questionnaires were then collected to analyze the data. Reliability test (Cronbach's Alpha) for the questionnaire (Table 1) show that the questionnaire is satisfactorily reliable.

\section{Table 1}

Questionnaire Reliability Test Results

\begin{tabular}{lc}
\hline Variable & \multicolumn{1}{c}{$\begin{array}{c}\text { Alpha } \\
\text { value }\end{array}$} \\
\hline Brand & 0.903 \\
Perceived quality & 0.905 \\
Complementary information & 0.903 \\
Price & 0.905 \\
Buying choice & 0.904 \\
Total Alpha & 0.904 \\
\hline
\end{tabular}

\subsection{Instruments}

The instrument used to collect the data was the questionnaire. Microsoft Excel 2010 was used for typing in the data from the paper questionnaires. The instrument used for statistical tests and data analysis was SPSS.

\section{Results}

The regression function model in this research has the four independent variables of the model and customer choice (dependent variable). Since independent variables adjust the effects of each other all four variables were simultaneously and successfully entered into the regression function (no variables eliminated). 
Table 2

Pearson correlation Coefficients for the theoretical model variables

\begin{tabular}{|c|c|c|c|c|c|c|}
\hline & & $\begin{array}{l}\text { Buying } \\
\text { choice }\end{array}$ & Brand & $\begin{array}{c}\text { Perceived } \\
\text { Quality }\end{array}$ & Price & $\begin{array}{c}\text { Complementary } \\
\text { information }\end{array}$ \\
\hline \multirow{5}{*}{$\begin{array}{c}\text { Pearson } \\
\text { correlation } \\
\text { coefficients }\end{array}$} & Buying choice & 1.000 & 0.560 & 0.328 & 0.606 & -0.037 \\
\hline & Brand & 0.460 & 1.000 & 0.066 & 0.426 & 0.276 \\
\hline & $\begin{array}{l}\text { Perceived } \\
\text { quality }\end{array}$ & 0.328 & 0.066 & 1.000 & 0.171 & $0.235-$ \\
\hline & Price & 0.606 & 0.426 & 0.171 & 1.000 & 0.019 \\
\hline & $\begin{array}{l}\text { Complementar } \\
\text { y information }\end{array}$ & -0.037 & 0.276 & -0.235 & 0.019 & 1.000 \\
\hline \multirow{5}{*}{ Significance } & Buying choice & - & 0.000 & 0.002 & 0.000 & 0.378 \\
\hline & Brand & 0.000 & - & 0.289 & 0.000 & 0.009 \\
\hline & $\begin{array}{l}\text { Perceived } \\
\text { quality }\end{array}$ & 0.002 & 0.289 & - & 0.073 & 0.022 \\
\hline & Price & 0.000 & 0.000 & 0.073 & - & 0.437 \\
\hline & $\begin{array}{l}\text { Complementar } \\
\text { y information }\end{array}$ & 0.378 & 0.009 & 0.022 & 0.437 & - \\
\hline
\end{tabular}

The ANOVA and Pearson Coefficients for the regression model (tables 2, 3) show that the variables correlations are significant enough to predict the dependent variable (buying choice) $(\mathrm{df}=4, \mathrm{~F}=15.5$ and significance: $0.00<0.05)$.

Table 3

ANOVA results for the regression function variables

\begin{tabular}{llccccc}
\hline \multicolumn{1}{c}{ Model } & $\begin{array}{c}\text { Sum of } \\
\text { Squares }\end{array}$ & $\boldsymbol{f}$ & $\begin{array}{c}\text { Average } \\
\text { Square }\end{array}$ & $\boldsymbol{F}$ & Sig. \\
\hline \multirow{2}{*}{1} & Regression & 3.80 & & 0.950 & & \\
Residual & 4.21 & 9 & 0.601 & 15.547 & 0.000 \\
& & & & & & \\
\hline
\end{tabular}

Table 4

Linear Regression Results

\begin{tabular}{|c|c|c|c|c|c|}
\hline \multirow[t]{2}{*}{ Regression model } & \multicolumn{2}{|c|}{$\begin{array}{l}\text { Non-standard } \\
\text { coefficient }\end{array}$} & \multirow{2}{*}{$\begin{array}{c}\text { Standardized } \\
\text { coefficients } \\
\text { Beta } \\
\end{array}$} & \multirow[t]{2}{*}{$t$} & \multirow[t]{2}{*}{ Sig. } \\
\hline & B & Error & & & \\
\hline Constant & 2.762 & 0.256 & 0.060 & 10.775 & 0.000 \\
\hline Brand & 0.139 & 0.052 & 0.272 & 2.685 & 0.009 \\
\hline Perceived Quality & 0.115 & 0.049 & 0.216 & 2.360 & 0.021 \\
\hline Price & 0.227 & 0.049 & 0.455 & 4.640 & 0.000 \\
\hline $\begin{array}{l}\text { Complementary } \\
\text { Information }\end{array}$ & $0.026-$ & 0.036 & $0.070-$ & -0.736 & 0.464 \\
\hline
\end{tabular}

The results of the regression text are presented in Table 4 . As table 4 shows, the Beta and the $t$ test values for brand are 0.272 and 10.775 respectively, with 0.009 significance level (smaller than 0.005). The Beta and t values for perceived quality are 0.216 and 2.360 
respectively at 0.021 significance level, also smaller than 0.005 . Further, Beta and $t$ test values for price are 0.455 and 4.640 , respectively. Beta and t text values for complementary information are -0.070 (negative) and -0.70 respectively at 0.467 significance level. Table 5 summarizes the results of testing the hypotheses of the present research based on beta and significance values of regression test.

Table 5

Hypotheses testing results

\begin{tabular}{lllcc}
\hline & \multicolumn{1}{c}{ Hypothesis } & \multicolumn{1}{c}{ Beta } & Alphavalue & Confirm/reject \\
\hline H1 & $\begin{array}{l}\text { In the buying process of } \\
\text { industrial lubricants, brand has a } \\
\text { more significant effect than } \\
\text { price. }\end{array}$ & $\begin{array}{l}\text { Price } \\
(0.277)\end{array}$ & 0.00 & rejected \\
B 1-1 & $\begin{array}{l}\text { Prand }(0.139) \\
\text { Price has a positive and } \\
\text { significant effect on buying } \\
\text { choice of industrial lubricants. } \\
\text { Brand has a positive and } \\
\text { significant effect on buying } \\
\text { choice of industrial lubricants. }\end{array}$ & 0.227 & 0.009 & confirmed \\
H 1-2 & 0.139 & 0.009 & confirmed \\
H 1-3 & $\begin{array}{l}\text { Brand has a positive and } \\
\text { significant effect on the quality } \\
\text { of industrial lubricants as } \\
\text { perceived by customers. } \\
\text { Perceived quality has a positive } \\
\text { and significant effect on buying } \\
\text { choice of industrial lubricants. } \\
\text { Complementary information has } \\
\text { a positive and significant effect } \\
\text { on buying choice of industrial } \\
\text { lubricants. }\end{array}$ & 0.060 & 0.341 & rejected \\
H 1-5 & 0.115 & 0.021 & confirmed \\
\hline
\end{tabular}

\section{Discussion and conclusion}

The demographic findings show that the respondents' age varies between 27 and 51 (40 per cent of 74 respondents stated age) and on average most respondents were 35 years old. In terms of sex, the majority of participants ( 77 per cent) were male leaving only 17 percent female in the sample population. The respondents mostly had associate or bachelor's degree with 11 (14.9 per cent) with higher education (master's or Ph.D. degree). Male experts dominated buying decision making roles. A large number (446 individuals) were in managerial positions in smaller organizations. Normally, such organizations with smaller workforce and prominent manager/owner's role in buying. This shows buying decision making is based on a systematic process relying on evaluation and expertise. In terms of tenure, on average respondents had 3 years of experience. Most respondents had a tenure of over 5 years (tenure $>6$ ) indicating most respondents had gained considerable experience regarding the brands/products. 
In buying organizations, high purchase volumes, consistent with Kotler (1999) was observed ( 25 < purchase volume <15000000 million Tomans). Among the brands, Behran enjoyed the highest purchase volume and growth in sales followed by Aria Sanat. Castrol ranked third and Iranol and Sepahan both stand fourth after Naft Pars. Four brands (i.e. Zeta, Adinol, Petromax and Govah) had the lowest sales rate. Also, 67 per cent of buyers operated in one area (spare parts and automotive supplements, manufacturing, or parts engineering) with essential role of lubricants for quality and profitability. Interestingly, buyers of three brands buy twice as much as those buying more brands. More advertised brands in most organizations was considered an important criterion in buying choice. Buyers most frequently learned and collected information about the seller through sales representatives, fairs, advertisements and to a lower degree internet surfing. Notably, most buyers used only one method (representatives) to get information. In addition, 51.3 per cent use only sales representative. As for purchase mechanism, 71.6 per cent buy through one method (i.e. legal agreements) as agreements characterize industrial purchase. This reflects price importance since price stability in high purchase volumes is ensured. Other methods (e.g. franchising and tenders) are not economically justifiable.

Regression results revealed the positive significant brand effect $(<0.05)$ on buying choice. That is, brand predicts buying choice particularly when only one to three brands (i.e. mostly Behran, Castrol and Aria Sanat) were bought. The price effect on buying choice (beta and t values, 0.455 and 4.640 at 0.00 significance) is slightly more significant leading to the rejection of the main hypothesis (table 5). This means price is slightly more significant in buying process and a better predictor of buying choice. Similarly, hypothesis 1-1 and 1-2 are both supported confirming the findings by Holden (2012) that price is the most important factor in industrial customers' buying choice as well as other previous studies (e.g. Zeb, Rashis, \& Javeed, 2011; Ojo, Kesinro, \& Akinsunmi, 2015; Baily, 2011) showing significant effect of brand awareness on industrial buyers' choice. Nevertheless, the finding contradicts with Abdulaziz \& Mustaffa (2015) who failed to find a positive brand awareness effect on buying choice, while generally support the positive effect of brand. However, Holden (2012) while confirming price significance, states in long-term seller-buyer relationships, price becomes less important as higher benefits of products lowers price sensitivity. Small customer number, high volumes, and purchase agreements decreases buyer's price concerns (Kotler \& Pfoertsch, 2007). 
The perceived quality (as mediator of mediating brand-buying correlation) does not significantly affect buying choice and thus hypothesis 1-4 is rejected. But it has a significant effect on buying choice, confirming hypothesis 1-5. rather the two variables independently influence buying choice. Conversely, Brucks, Zeithmal, \& Naylor (2007) confirming the direct significant effect of both variables on buying choice, report an indirect effect of brand mediated by perceived quality. However, the finding is in line with Ojo, Kesinro, \& Akinsunmi (2015) and Dhrup, Mafini, \& Dumasi (2014) and Heidarzadeh, Alvani, \& Ghalandari (2011). The findings rejected the hypothesis that customer's complementary information of industrial lubricants has a positive and significant effect on buying choice indicating that information does not have an effect on buying choice and buyers are less likely to consider the factor in purchase decision. This contrasts with previous findings (i.e. Kotler, 1999; Brucks, Zeithmal, \& Naylor, 2007; Zakir \& Naeemkhan, 2011).

\section{Limitations}

The present research has some limitations in terms of generalization of the findings. First, the population was limited to lubricant buying organizations in Tehran , Iran and generalizing the results has be made with care and consideration of sociocultural and geographical differences. Second, the sample size was limited. Third, the correlations among the variables was quantitatively determined; some qualitative contextual information could be helpful. Data collection was limited to buyers and does not reflect sellers' viewpoints. Fourth, data collection instrument was self-report questionnaire and subjectivity may limit results applicability. Finally, the survey included only one representative per organization.

\section{Future Research Suggestions}

Future studies in the field of industrial marketing are encouraged to replicate this study in other provinces and cities of Iran and with larger sample sizes, as well as in other countries and regions. Other industrial markets could be studied using the similar methodology. Future studies should be conducted on buying behavior using a mixed method and in other market sectors. Future research using larger sample sizes are encouraged. Comparing sellers and buyer's perspectives, in a single study could yield better understanding of buying choice in industrial markets. 


\section{References}

Abdulaziz, Y., \& Mustaffa, M. (2015). Corporate Brand Expressions in Industrial Brand: Evidence ftom Malaysia. Social Sciences and Technology Management, 601 - 608.

Balalian, A. A., Simonyan, H., Hekimian, K., Deckelbaum, R. J., \& Sargsyan, A. (2017). Prevalence and determinants of stunting in a conflict-ridden border region in Armenia-a cross-sectional study. BMC Nutrition, 3(1), 85.

Baily, F. J. (2011). Customer buying Behavior at Selected Petroleum Shops in Cape Town. Cape Town: Cape Peninsula University of Technology.

Bingham, F. G. (2012). Business to Business Marketing Management. Homewood: Irwin.

Brucks, M., Zeithmal, A. V., \& Naylor, G. (2007). Price and Brand Name as Indicators of Quality Dimensions for Customer Durables. Journal of Academy of Marketing Science, 359 $-374$.

Dehdashti, Z., \& Kohiari, A. (2015). The Effect of Industrial Brand Value on Brand Performance from the View of Buying Center: Study Case Home Appliances Producing Companies. Business Management.

Dhrup, M., Mafini, C., \& Dumasi, T. (Acts Commercii). The Impact of Packaging, Price, and Brand Awareness on Brand Loyalty: Evidence from the Paint Retailing Industry. 2014, 194 $-203$.

Heidarzadeh, K., Alvani, M., \& Ghalandari, K. (2011). Investigating the Effects of Social Power Dimensions of Brand based on Mental Preparedness of Customers on Buying Decision. Management Research, 86.

Holden, N. (2012). Strategy and Tactics of Pricing: Making profitable Decisions . Englewood Cliffs, NJ: Prentice-Hall .

Johnston, J. W., Lewin, E. J., \& Spekman, E. R. (2009). International Industrial Marketing Interactions: Dyadic and Network Perspectives. Journal of Business Research, 259 - 271.

Keshavarzi Bank Securities Co. (2015). Industrial Analysis of Lubricant Producers. Retrieved from Bank Keshavarzi Securities Co. Website: http://www.bkisecurities.com

Kotler, P. (1999). On Marketing: How to Create, Win, and Dominate Markets. New York: Free Press.

Kotler, P., \& Pfoertsch, W. (2007). Being Unkown or Being one of the Many: the Need for Brand Management for Business-to-Business (B2B) Companies. Journal of Business Industrial Markets, 357 - 362.

Majumder, K. (2015). A Young Researcher's Guide to a Systematic Review. Japan: Editage. 

customers' buying choice

Ojo, O. J., Kesinro, R. O., \& Akinsunmi, A. (2015). Brand Recognition and Impulse Buying Behavior of Automitive Lubricants in Lagos State, Nigeria. European Journal of Business, Economics and Accountancy, 51 - 63.

Seydjavadin, R., Amini, A., \& Amini, Z. (2014). Evaluating the Effect of Brand on Industrial Customer Loyalty. Business Management Perspective.

Srivastava, G. (2013). Brand Positioning and Automotive Lubricant in Indian MArket. International Journal of Management, 2(4), 43 - 55.

Zakir, S., \& Naeemkhan, F. (2011). Consumer Attitude towards Automobile Lubricants: A Case Study of PSO Lubricants. Journal of Independent Studies and Research, 31 - 45.

Zeb, H., Rashis, R., \& Javeed, B. (2011). Influence of Brands on Female Consumer's Buying behavior in Pakistan. International Journal of Trade Economics and Finance, 225 - 231. 